\title{
Effects of non-steroidal anti-inflammatory drugs and prostaglandins on alkali secretion by rabbit gastric fundus in vitro
}

\author{
W D W REES, L C GIBBONS, AND L A TURNBERG \\ From the University Department of Medicine, Hope Hospital, Salford.
}

SUMMARY The effects of non-steroidal anti-inflammatory drugs and prostaglandins $E_{2}$ and $F_{2 \alpha}$ on the secretory and electrical activity of isolated rabbit fundic mucosa have been studied. Spontaneous acid secretion was inhibited by serosal side application of sodium thiocyanate $\left(6 \times 10^{-2} \mathrm{M}\right)$ and the resulting alkali secretion measured by $\mathrm{pH}$ stat tiration. Serosal side application of indomethacin $\left(10^{-5} \mathrm{M}\right)$ or aspirin $\left(3 \times 10^{-3} \mathrm{M}\right)$ inhibited alkali secretion $(0.55 \pm 0.06$ to $0.12 \pm 0.06 \mu \mathrm{mol} / \mathrm{cm}^{2} / \mathrm{h}, \mathrm{n}=6, \mathrm{p}<0.01$ and $0.28 \pm 0.06$ to $0.11 \pm 0.03 \mu \mathrm{mol} / \mathrm{cm}^{2} / \mathrm{h}, \mathrm{n}=7, \mathrm{p}<0.02$ respectively). Mucosal or serosal side prostaglandin $E_{2}\left(10^{-5}\right.$ to $\left.10^{-10} \mathrm{M}\right)$ and $\mathrm{F}_{2 \alpha}\left(10^{-4}\right.$ to $10^{-10} \mathrm{M}$ ) failed to alter the rate of alkalinisation but secretion was significantly increased by serosal side 16,16 -dimethyl-prostaglandin $E_{2}\left(10^{-6} \mathrm{M}\right)\left(0.90 \pm 0.20\right.$ to $1.50 \pm 0.30 \mu \mathrm{mol} / \mathrm{cm}^{2} / \mathrm{h}$, $n=6, p<0 \cdot 01$ ). Serosal side application of $10^{-6} M$ prostaglandin $E_{2}$ to fundic mucosae pretreated with either aspirin $\left(5 \times 10^{-3} \mathrm{M}\right)$ or indomethacin $\left(10^{-5} \mathrm{M}\right)$, to reduce endogenous $\mathrm{E}_{2}$ formation, also failed to alter alkali secretion. Pretreatment of the mucosa with 16,16 -dimethyl- $\mathrm{E}_{2}\left(10^{-6} \mathrm{M}\right)$ abolished the inhibitory effect of indomethacin $\left(10^{-5} \mathrm{M}\right)$ on alkali secretion $(n=6)$ but did not modify the secretory response to aspirin $\left(3 \times 10^{-3} \mathrm{M}\right)$ (fall in alkali secretion with aspirin = $81 \pm 11 \%$ and with aspirin plus 16,16 -dimethyl- $\mathrm{E}_{2}=72 \pm 10 \%, \mathrm{n}=7$ ). In the doses used, none of the prostaglandins or non-steroidal anti-inflammatory drugs altered transmucosal potential difference or electrical resistance. These results show that the damaging agents, aspirin and indomethacin, both inhibit gastric alkali secretion but that modes of action may differ. The observation that prostaglandins, $\mathrm{E}_{2}$ and $\mathrm{F}_{2 \alpha}$ failed to increase alkali production suggests that their protective activity against a variety of damaging agents as shown by others, may be mediated by another mechanism.

Studies in animals and man have shown that non-steroidal anti-inflammatory drugs, such as aspirin and indomethacin, cause acute gastric mucosal damage. ${ }^{1-4}$ The precise mechanism of such damage remains unknown although early experiments by Davenport suggested that these agents may disrupt a mucosal 'barrier' to hydrogen ion diffusion..$^{5-7}$ In recent years an alternative hypothesis has emerged which suggests that damage follows inhibition of non-parietal alkali secretion ${ }^{89}$ with subsequent failure of acid neutralisation at the

Address for correspondence: Dr W D W Rees Department of Medicine. Hope Hospital, University of Manchester School of Medicine. Eccles Old Road. Salford M6 8HD.

Received for publication 2 November 1982 mucosal surface within the mucous gel layer. ${ }^{10}$ In support of this concept is the observation that prostaglandins, which are known to protect the stomach from damage by a variety of noxious agents, ${ }^{11}$ - stimulate alkali secretion and prevent the inhibition of alkalinisation produced by nonsteroidal anti-inflammatory drugs. ${ }^{12-14}$

Many of these observations on alkali secretion, however, have been derived from experiments on amphibian gastric mucosa. ${ }^{12} 13$ We have recently developed an isolated mammalian fundus preparation ${ }^{15}$ and have used this to examine the effect of the anti-inflammatory drugs, aspirin and indomethacin, and the prostaglandins, 16,16dimethyl- $E_{2}, E_{2}$ and $F_{2 \alpha}$ on mammalian alkali secretion. 


\section{Methods}

EXPERIMENTAL PROCEDURE

Experiments were performed on gastric mucosa from male New Zealand White rabbits. The animals were killed by air embolus and the fundus of the stomach excised, washed with warm, unbuffered solution and the external muscle layer removed by blunt dissection in oxygenated unbuffered solution at $37^{\circ} \mathrm{C}$. The mucosa was then mounted between two halves of a perspex chamber (surface area 1.8 $\mathrm{cm}^{2}$ ) and each surface bathed with $20 \mathrm{ml}$ of solution maintained at $37^{\circ} \mathrm{C}$ and circulated by gas lifts (gassing with a fine bore tube). The unbuffered luminal side solution was kept at a constant $\mathrm{pH}$ $(7.40)$ by infusion of either sodium hydroxide (15 $\mathrm{mmol})$ or hydrochloric acid $(5 \mathrm{mmol})$ using a $\mathrm{pH}$ stat system (ABU 80 and TTT 80, Radiometer, Copenhagen, Denmark). Secretory rate was calculated from the volume of titrants infused and expressed as $\mu \mathrm{mol} / \mathrm{cm}^{2} / \mathrm{h}$. Open circuit potential difference was measured using matched calomel electrodes and recorded on a high-input impedance voltmeter (Servoscribe $2 \mathrm{~s}$ ). The dc electrical resistance was determined at 5 minute intervals from the immediate fall in potential difference produced by passing a fixed external current (30 $\mu$ Amps) through the tissue using silver:silver chloride electrodes.

\section{BATHING SOLUTIONS}

The serosal side solution contained $\mathrm{Na}^{+}(133.3$ $\mathrm{mmol}), \mathrm{K}^{+}(4.0 \mathrm{mmol}), \mathrm{Ca}^{2+}(1.8 \mathrm{mmol}), \mathrm{Mg}^{2+}(0.8$ $\mathrm{mmol}), \mathrm{Cl}^{-}(122.3 \mathrm{mmol}), \mathrm{HCO}_{3}^{-}(17.8 \mathrm{mmol})$, $\mathrm{H}_{2} \mathrm{PO}_{4}^{-}(0.8 \mathrm{mmol}), \mathrm{SO}_{4}^{2-}(0.8 \mathrm{mmol})$ and glucose $(20 \mathrm{mmol})$. The solution was gassed with a mixture of $95 \%$ oxygen and $5 \%$ carbon dioxide and had a final $\mathrm{pH}$ of $7 \cdot 20$. The luminal side solution was unbuffered, the $\mathrm{HCO}_{3}^{-}$and $\mathrm{H}_{2} \mathrm{PO}_{4}^{-}$being replaced by $\mathrm{SO}_{4}^{2-}(9.3 \mathrm{mmol})$, glucose omitted and mannitol added (11.3 mmol) to produce the same osmolarity as the serosal side solution. This solution was gassed with $100 \%$ oxygen, prewashed with saturated barium hydroxide to remove traces of carbon dioxide, and maintained at $\mathrm{pH} 7 \cdot 40$. Titrants were of similar electrolyte composition to the mucosal side solution.

\section{DRUGS AND CHEMICALS}

The following drugs and chemicals were used: sodium thiocyanate (BDH Pharmaceuticals), aspirin, indomethacin, prostaglandin $\mathrm{E}_{2}$ and prostaglandin $\mathrm{F}_{2 \alpha}$ (Sigma Chemical Co, St Louis, Mo). 16,16-dimethyl-prostaglandin $\mathrm{E}_{2}$ was a kind gift of Dr J Pike, Upjohn, Kalamazoo, Michigan. With the exception of $\mathrm{PGE}_{2}$ and $\mathrm{PGF}_{2 \alpha}$ the compounds were added to the serosal side solution only, the appropriate stock solution being adjusted to the correct $\mathrm{pH}$ immediately before use. The concentration of each stock solution was adjusted so that addition of $100 \mu$ lo the $20 \mathrm{ml}$ bathing solution (in the case of aspirin $1 \mathrm{ml}$ of a $60 \mathrm{mmol}$ aspirin stock solution) produced the desired final concentration. In preliminary experiments, addition of up to $1 \mathrm{ml}$ of 'control' solution to the nutrient side did not alter the rate of secretion by the mucosa. For mucosal side administration, stock solutions of $E_{2}$ and $F_{2 \alpha}$ were prepared at $\mathrm{pH} 7.4$ so that $10 \mu$ l produced the desired final concentration.

STATISTICAL ANALYSIS

Secretory rate, potential difference and electrical resistance were recorded at 5 minute intervals and mean values for consecutive 15 minute periods calculated from each experiment. In the Figures, the mean and standard error of each series of experiments is presented and statistical significance calculated by comparing data obtained before and after addition of a compound using Student's paired $t$ test.

\section{Results}

EFFECT OF INDOMETHACIN AND ASPIRIN ON ALKALI SECRETION

As previously described, ${ }^{15}$ serosal side application of sodium thiocyanate $\left(6 \times 10^{-2} \mathrm{M}\right)$ inhibited basal acid secretion thus allowing measurement of net alkali secretion. Secretory rates by these mucosae remained stable over a three hour period although the magnitude of alkali production showed marked variation among animals. Thus, with small numbers of animals, basal rates of alkali secretion were markedly different in some experiments and in evaluating the effect of various agents on the rate of alkalinisation, each animal acted as its own control and comparisons were not made between different series of experiments.

Addition of $10^{-5} \mathrm{M}$ indomethacin to the serosal side solution produced an immediate and sustained fall in the rate of alkalinisation from $0.55 \pm 0.06$ to $0.12 \pm 0.06 \mu \mathrm{mol} / \mathrm{cm}^{2} / \mathrm{h} \quad(\mathrm{n}=6, \mathrm{p}<0.01 ;$ Fig. 1). $10^{-6} \mathrm{M}$ indomethacin produced only a slight and insignificant fall in alkali production (results not shown). Serosal side aspirin $\left(3 \times 10^{-3} \mathrm{M}\right)$ produced a similar decrease in the rate of alkali secretion $\left(0.28 \pm 0.06\right.$ to $0.11 \pm 0.03 \mu \mathrm{mol} / \mathrm{cm}^{2} / \mathrm{h}, \mathrm{n}=7, \mathrm{p}<0.02$, Fig. 2), but $10^{-4} \mathrm{M}$ aspirin was without effect (results not shown). Neither drug altered transmucosal potential difference $(9 \pm 1 \mathrm{mV}, \mathrm{n}=6$, for indomethacin and $10 \pm 1 \mathrm{mV}, \mathrm{n}=7$, for aspirin) or electrical resistance $\left(44 \pm 4 \mathrm{Ohm} / \mathrm{cm}^{2}, \mathrm{n}=6\right.$ and $38 \pm 6$ 


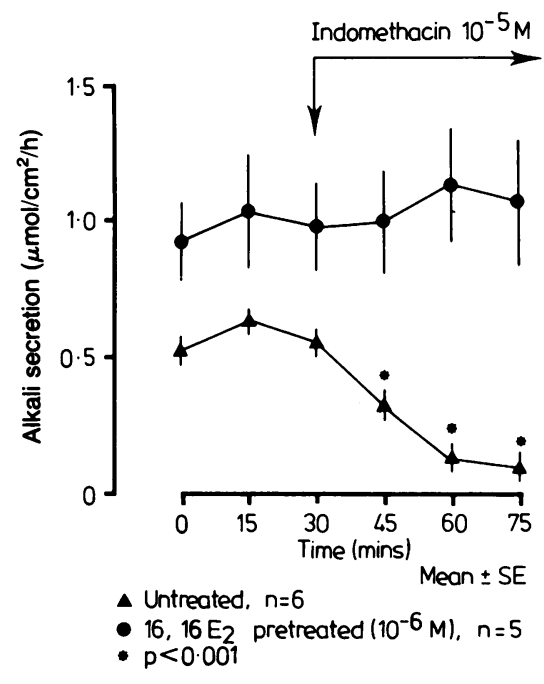

Fig. 1 Effect of serosal side indomethacin $\left(10^{-5} \mathrm{M}\right)$ on alkali secretion by rabbit fundic mucosa. Values represent means $\pm S E$ of six control $(\Delta)$ and 5 16,16-dimethylprostaglandin $E_{2}$ pre-treatment $(\bullet)$ experiments. Student's paired $\mathrm{t}$ evaluation was carried out on pre-and postexposure results.

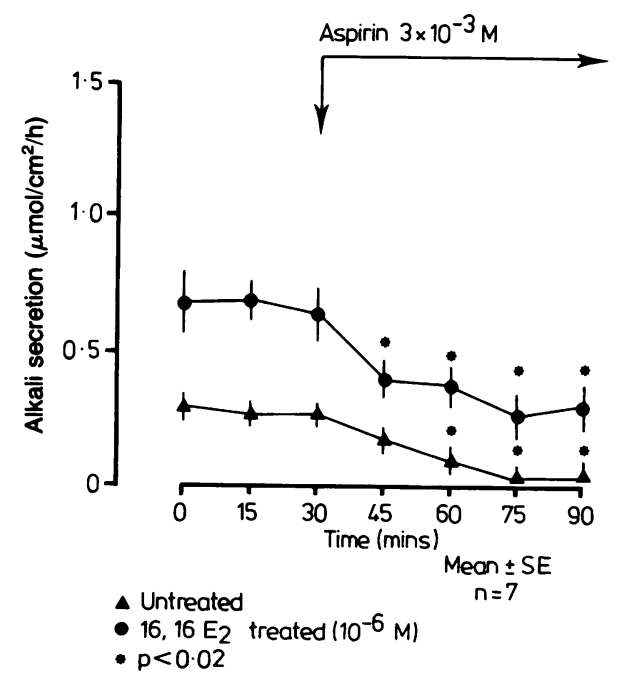

Fig. 2 Effect of serosal side aspirin $\left(3 \times 10^{-3} \mathrm{M}\right)$ on alkali secretion by rabbit fundic mucosa. Values represent means $\pm S E$ of seven control ( $\Delta)$ and 716,16-dimethylprostaglandin $E_{2}$ pre-treatment $(\bullet)$ experiments. Student's paired $\mathrm{t}$ evaluation was carried out on pre-and postexposure values.
$\mathrm{Ohm} / \mathrm{cm}^{2}, \mathrm{n}=7$, respectively) of the mucosa at the doses used.

In a separate series of experiments on mucosae which had not been treated with sodium thiocyanate, $10^{-5} \mathrm{M}$ indomethacin and $3 \times 10^{-3} \mathrm{M}$ aspirin did not alter basal acid secretion (control = $1.20 \pm 0.20$ and indomethacin $=1.30 \pm 0.20 \mu \mathrm{mol} /$ $\mathrm{cm}^{2} / \mathrm{h}, \mathrm{n}=6$; Control $=1 \cdot 80 \pm 0.60$ and aspirin = $\left.1.80 \pm 0.50 \mu \mathrm{mol} / \mathrm{cm}^{2} / \mathrm{h}, \mathrm{n}=4\right)$.

\section{EFFECT OF EXOGENOUS PROSTAGLANDINS ON ALKALI SECRETION}

Addition of prostaglandin $E_{2}$ to the serosal $\left(10^{-5}\right.$ to $\left.10^{-7} \mathrm{M}\right)$ or mucosal $\left(10^{-7}\right.$ to $\left.10^{-10} \mathrm{M}\right)$ side solutions did not significantly alter the rate of alkali production by fundic mucosa pretreated with sodium thiocyanate. Similar results were obtained using serosal $\left(10^{-4}\right.$ to $\left.10^{-10} \mathrm{M}\right)$ and mucosal $\left(10^{-6}\right.$ to $10^{-10} \mathrm{M}$ ) applications of prostaglandin $\mathrm{F}_{2 \alpha}$. Addition of the stable prostaglandin analogue, 16,16-dimthyl$\mathrm{E}_{2}\left(10^{-6} \mathrm{M}\right)$ to the serosal side solution, however, produced a significant increase in the rate of alkalinisation from $0.90 \pm 0.20$ to $1.50 \pm 0.30 \mu \mathrm{mol} /$ $\mathrm{cm}^{2} / \mathrm{h}, \mathrm{n}=6 ; \mathrm{p}<0.01$ (Fig. 3). In control

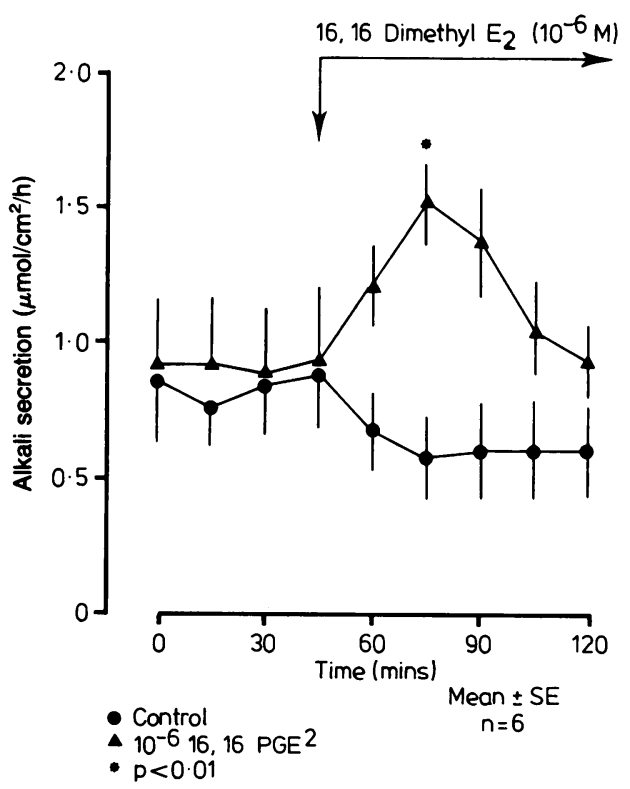

Fig. 3 Effect of serosal side 16,16 dimethyl prostaglandin $E_{2}\left(10^{-6} \mathrm{M}\right)$ on alkali secretion by rabbit fundic mucosa. Values represent means $\pm S E$ of six control ( $\bullet$ ) and six prostaglandin $(\mathbf{\Delta})$ experiments. Student's paired $\mathbf{t}$ evaluation was carried out on pre-and post-exposure values. 
experiments, where saline only was added to the serosal side, rates of alkali secretion remained stable (Fig. 3). None of the prostaglandins studied had any effect on transmucosal potential difference or electrical resistance of the mucosa.

EFFECT OF PROSTAGLANDIN E 2 ON ALKALI SECRETION BY FUNDIC MUCOSA PRETREATED WITH $5 \times 10^{-3} \mathrm{M}$ ASPIRIN OR $10^{-5} \mathrm{M}$ INDOMETHACIN As endogeneous production of prostaglandin during preparation and mounting of the mucosa may mask any stimulatory effect of exogenous prostaglandins, a series of experiments was carried out in which the mucosa was stripped in a solution containing either $5 \times 10^{-3} \mathrm{M}$ aspirin or $10^{-5} \mathrm{M}$ indomethacin and the mucosa subsequently exposed to serosal side $5 \times 10^{-3} \mathrm{M}$ aspirin or $10^{-5} \mathrm{M}$ indomethacin in the chamber for a 30 minute period. Mucosal and serosal solutions were then replaced with drug free solutions and sodium thiocyanate $\left(6 \times 10^{-2} \mathrm{M}\right)$ added to the serosal side as previously described. Basal secretory rate was recorded when alkalinisation or acidification of the mucosal solution appeared stable (approximately 90 to 120 minutes after adding thiocyanate) and prostaglandin $E_{2}$ added after a 45 minute control period. Potential difference $(9 \cdot 2 \pm 0 \cdot 9$ $\mathrm{mV}$ for aspirin and $10 \cdot 1 \pm 0 \cdot 8 \mathrm{mV}$ for indomethacin,

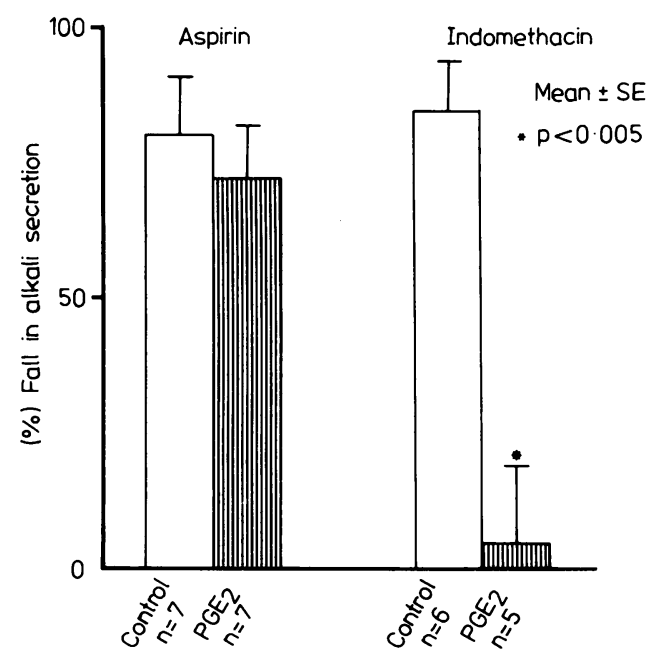

Fig. 4 Effect of 16,16-dimethyl-prostaglandin $E_{2}\left(10^{-6} \mathrm{M}\right)$ on percent fall in alkali secretion produced by aspirin $\left(3 \times 10^{-3} \mathrm{M}\right)$ and indomethacin $\left(10^{-5} \mathrm{M}\right)$. Values represent means $\pm S E$ and were derived by comparing the rate of alkali secretion over 15 minute periods immediately before and after drug administration (n represents the number of experiments performed). $\mathrm{n}=6)$ and electrical resistance $(33 \pm 4$ and $37 \pm 3$ $\mathrm{Ohm} / \mathrm{cm}^{2}$ respectively, $\mathrm{n}=6$ ) were not significantly different from tissues not pretreated with these agents. Some of the aspirin and indomethacin treated mucosae, however, failed to exhibit alkali secretion and secreted acid throughout the study period. Addition of prostaglandin $\mathrm{E}_{2}\left(10^{-5}\right.$ and $10^{-6} \mathrm{M}$ ) to the serosal side solutions of these mucosae failed to alter the rate of alkali production $(n=6)$ or acid secretion $(n=6)$.

EFFECT OF I 6, I 6-DIMETHYL-PROSTAGLANDIN E 2 ON SECRETORY RESPONSE TO INDOMETHACIN AND ASPIRIN

Pretreatment of fundic mucosa with serosal side 16,16 -dimethyl- $E_{2}\left(10^{-6} \mathrm{M}\right)$ for 30 minutes completely prevented the fall in alkali secretion produced by $10^{-5} \mathrm{M}$ indomethacin (Figs. 1 and 4 ). The response to $3 \times 10^{-3} \mathrm{M}$ aspirin, however, was not modified; the fall in alkali secretion immediately after aspirin exposure being $81 \pm 11 \%$ in untreated mucosae and $72 \pm 10 \%$ in the prostaglandin treated mucosae $(n=7)$ (Figs. 2 and 4$)$. It may be seen from Fig. 4 that the doses of aspirin and indomethacin used produced similar inhibition of basal alkali secretion.

\section{Discussion}

A number of recent observations have supported the hypothesis that gastric alkali secretion plays an important role in protecting the stomach from damage by intraluminal acid. ${ }^{16}$ Firstly, alkali secretion has been shown in a number of in vitro and in vivo gastric preparations ${ }^{89}$ and by the intact human stomach. ${ }^{17}$ Secondly, damaging agents such as non-steroidal anti-inflammatory drugs and bile salts inhibit this secretion in amphibia in vitro and in man in vivo ${ }^{13}$ 18-20 while some 'protective' prostaglandins have been shown in amphibian species to both stimulate basal secretion ${ }^{12}$ and prevent the inhibitory effect of non-steroidal antiinflammatory drugs. ${ }^{13}$ Thirdly, studies with microelectrodes have shown the existence of a $\mathrm{pH}$ gradient across the unstirred mucus gel layer covering mammalian and human gastric mucosa. ${ }^{102122}$ The epithelial cell surface is thus bathed with fluid at a neutral $\mathrm{pH}$ despite the presence of intraluminal acid.

We have recently provided further support for this hypothesis by showing active bicarbonate transport in an isolated mammalian (rabbit) fundus preparation ${ }^{15}$ thus confirming the applicability of the studies in amphibia. The characteristics of alkali secretion by this mucosa are similar to those of amphibian gastric mucosa ${ }^{23}$ and the bile salt, sodium 
taurocholate inhibited alkali secretion in both species. ${ }^{1519}$ In the present study we have shown that alkali secretion by rabbit fundic mucosa is inhibited by the non-steroidal drugs, aspirin, and indomethacin and stimulated by 16,16-dimethylprostaglandin $\mathrm{E}_{2}$. In addition pretreatment with 16,16-dimethyl-PGE 2 abolished the inhibitory effect of indomethacin on alkali secretion as in amphibian experiments and all of these observations are compatible with the hypothesis that alkali secretion is a protective process controlled by endogenous prostaglandin production.

Not all of our observations, however, fit tidily with this concept. Prostaglandins $E_{2}$ and $F_{2 \alpha}$ have been shown to protect gastric mucosa against a variety of agents but in the present study neither stimulated alkali secretion and only $F_{2 \alpha}$ did so in amphibian fundus. ${ }^{13}$ It is possible that these prostaglandins were rapidly metabolised to inactive products in the rabbit mucosa leaving only the stable analogue to produce an obvious response. Even under the most favourable circumstances, however, when endogenous prostaglandin synthesis was inhibited by indomethacin or aspirin, prostaglandin $E_{2}$ in high concentration did not influence alkali secretion. The possibility thus has to be entertained that the protective properties of these prostaglandins are not mediated by stimulation of alkali secretion. Prostaglandins have been shown to increase the thickness of the mucus gel layer, ${ }^{24} 25$ reduce gastric mucosal cell $\operatorname{loss}^{26}$ and modify mucosal blood flow ${ }^{27}$ and these effects may play a more important role in their protective activity. Furthermore there is a discrepancy between the effects of 16,16-dimethyl-prostaglandin $E_{2}$ on the inhibition of alkali secretion by indomethacin and aspirin. The inhibition by indomethacin was prevented while the response to aspirin was unaffected by this analogue suggesting that in the latter case protection against mucosal damage by aspirin is not mediated by effects on alkali secretion. This observation also suggests that aspirin and indomethacin may inhibit alkali secretion by different mechanisms. Indomethacin may inhibit secretion by reducing endogenous prostaglandin production as its effect is nullified by exogenous prostaglandin analogue. Aspirin, which accumulates in epithelial cells after topical application ${ }^{28}$ may, however, inhibit alkali secretion by an alternative mechanism, possibly by influencing formation or secretion of bicarbonate directly. Alternatively aspirin may inhibit production by the mucosa of other possibly more relevant, arachidonate metabolites whose action cannot be replaced by the exogenous prostaglandins used in these studies.

Thus, our study while providing further support for the idea that alkali secretion protects the stomach from damage raises some doubt as to whether exogenous prostaglandins exert their protective effects by influencing alkali secretion.

The authors wish to thank The Medical Research Council and the Wellcome Trust for financial support, the Department of Medical Illustration, Hope Hospital, Salford, for preparing the figures and Mrs J Rostron for typing the manuscript. WDW Rees was a Wellcome Senior Research Fellow.

\section{References}

1 Lanza FL, Royer GL, Nelson RS, Chen TT, Seckman CE, Rack MF. The effects of Ibuprofen, indomethacin, aspirin, naproxen, and placebo on the gastric mucosa of normal volunteers. Dig Dis Sci 1979; 24: 823-8.

2 Pemberton RE, Strand LJ. A review of upper gastrointestinal effects of the newer non-steroidal antiinflammatory agents. Dig Dis Sci 1979; 24: 53-64.

3 Lanza FL, Royer GL, Nelson RS. Endoscopic evaluation of the effects of aspirin, buffered aspirin and enteric coated aspirin on gastric and duodenal mucosa. $N$ Engl J Med 1980; 303: 136-8.

4 Rees WDW, Turnberg LA. Reappraisal of the effects of aspirin on the stomach. Lancet 1980; 2: 409-13.

5 Davenport HW. Salicylate damage to the gastric mucosal barrier. $N$ Engl J Med 1967; 276: 1307-12.

6 Davenport HW. Fluid produced by the gastric mucosa during damage by acetic and salicylic acid. Gastroenterology 1966; 50: 487-99.

7 Davenport HW. Gastric mucosal injury by fatty and acetyl salicylic acids. Gastroenterology 1964; 46: 24553.

8 Allen A, Garner A. Mucus and bicarbonate secretion in the stomach and their possible role in mucosal protection. Gut 1980; 21: 249-62.

9 Rees WDW, Turnberg LA. Biochemical aspects of gastric secretion. Clin Gastroenterol 1981; 10: 521-54.

10 Ross IN, Bahari HMM, Turnberg LA. The $\mathrm{pH}$ gradient across mucus adherent to rat fundic mucosa in vivo and the effect of potential damaging agents. Gastroenterology 1981; 81: 713-8.

11 Robert A. Prostaglandins and digestive diseases. $A d v$ Prostaglandin Thromboxane Res 1980; 8: 1533-41.

12 Garner A, Heylings JR. Stimulation of alkaline secretion in amphibian isolated gastric mucosa by 16,16 dimethyl $\mathrm{PGE}_{2}$ and $\mathrm{PGF}_{2 \alpha}$. Gastroenterology 1979; 76: 497-503.

13 Garner A, Flemstrom G, Heylings JR. Effects of anti-inflammatory agents and prostaglandins on acid and bicarbonate secretions in the amphibian-isolated gastric mucosa. Gastroenterology 1979; 77: 451-7.

14 Kauffman GL, Reeve JJ, Grossman MI. Gastric bicarbonate secretion: effect of topical and intravenous 16,16 dimethyl prostaglandin $\mathrm{E}_{2}$. Am J Physiol 1980; 239: G44-8.

15 Rees WDW, Garner A, Turnberg LA, Gibbons LC. Studies of acid and alkaline secretion by rabbit gastric 
fundus in vitro: effect of low concentration of sodium taurcholate. Gastroenterology 1982; 83: 435-40.

16 Hollander F. The two component mucous barrier. Arch Intern Med 1954; 94: 107-20.

17 Rees WDW, Botham D, Turnberg LA. A demonstration of bicarbonate production by the normal human stomach in vivo. Dig Dis Sci 1982; 27: 961-6.

18 Garner A. Effects of acetylsalicylate on alkalinisation, acid secretion and electrogenic properties in the isolated gastric mucosa. Acta Physiol Scand 1977; 99: 281-91.

19 Rees WDW, Garner A, Vivian KHB, Turnberg LA. Effect of sodium taurocholate on secretion by amphibian gastric mucosa in vitro. Am J Physiol 1981; 240: G245-9.

20 Rees WDW, Warhurst G, Turnberg LA. Studies of bicarbonate secretion by the normal human stomach in vivo: effect of sodium taurocholate and aspirin. (Abstract). Gastroenterology 1982; 82: 1158.

21 Williams SE, Turnberg LA. The demonstration of a $\mathrm{pH}$ gradient across mucus adherent to rabbit gastric mucosa: evidence for a 'mucus-bicarbonate' barrier. Gut 1981; 22: 94-6.

22 Bahari HMM, Ross IN, Turnberg LA. Demonstration of a $\mathrm{pH}$ gradient across the mucus layer on the surface of human gastric mucosa in vitro. Gut 1982; 23: 513-6.

23 Flemstrom G. Active alkalinization by amphibian gastric fundic mucosa. Am J Physiol 1977; 233: E1-12.

24 Bickel M, Kauffman GL. Gastric gel mucus: effect of distension, 16,16 dimethyl prostaglandin $E_{2}$ and carbenoxolone. Gastroenterology 1981; 80: 770-5.

25 Kerss S, Allen A, Garner A. A simple method for measuring thickness of the mucus gel layer adherent to rat, frog and human gastric mucosa: influence of feeding, prostaglandin, $\mathrm{N}$-acetyl cystein and other agents. Clin Sci 1982; 63: 187-95.

26 Garner A, Hurst BC. Gastric bicarbonate secretion and mucosal cell loss in the dog. In: Harmon JW, ed. Basic mechanisms of gastrointestinal mucosal cell injury and protection. Baltimore, USA: Williams and Wilkins, 1981: 273-89.

27 Kauffman GL, Whittle BJR. Gastric vascular actions of prostanoids and the dual effect of arachidonic acid. Am J Physiol 1982; 242: G582-7.

28 Garner A. Mechanisms of action of aspirin on the gastric mucosa of the guinea pig. Procedures of a Symposium on Gastric Ion Transport. Acta Physiol Scand (Special Suppl) 1978; 101-10. 